\title{
International Empirical Findings about the Success of Education and School Policy
}

\author{
Tristan Nguyen ${ }^{1} \&$ Mathias Pfleiderer ${ }^{1}$ \\ ${ }^{1}$ WHL Graduate School of Business and Economics, Lahr, Germany \\ Correspondence: Tristan Nguyen, Department of Economics/Insurance and Health Economics, WHL Graduate \\ School of Business and Economics, Hohbergweg 15-17, D-77933 Lahr, Germany. Tel: 49-078-2192-3865. \\ E-mail: tristan.nguyen@whl-lahr.de
}

Received: November 7, 2012 Accepted: November 16, 2012 Online Published: January 21, 2013

doi:10.5539/ies.v6n2p188 URL: http://dx.doi.org/10.5539/ies.v6n2p188

\begin{abstract}
The PISA studies in recent years have disclosed fundamental problems in the educational and training systems of many countries. According to the studies, it seems that simply increasing the education expenditures per pupil regularly does not sufficiently achieve better pupil performances. This "input-oriented" policy does not have any direct effect on the output in the form of better results by the pupils. Therefore, it is the objective of this essay to analyze the framework conditions in which an education system can develop optimally so that the pupils achieve better grades and/or performance at schools. We focus our analysis on the institutional factors such as "competition in the school system," "school autonomy," "responsibility," as well as a suitable combination of these factors. The research results of international empirical studies discussed in this paper provide a range of approaches and proposals that governments could use as a guide or as a "cornerstone" for the design of their schools and education systems.
\end{abstract}

Keywords: PISA, education, human capital, school performance

\section{Necessary Rethinking of Education and Training Policy}

Over the last few years, politicians in many European countries have been made aware of the problems in their schools and education systems by the PISA studies. According to the investigations, increasing the educational spending per student regularly does not satisfactorily achieve better student performance. Investments do not reach the pupils in the end because they disappear in bureaucratic processes. This is partly due to the opportunistic behavior of school managers and teachers. This "input-oriented" policy does not have any direct effects on the output in the form of better results by the pupils.

Therefore, governments and politicians generally need to change their thinking to improve the qualitative approaches of education. This was done in part by the European Qualifications Framework (EQF) in April 2008 for instance. The EQF has an "output-based" view and refers to what pupils actually learned and what kind of knowledge and skills they acquired after completing their training programs. It is the responsibility of the state to create the corresponding framework in which the school and training system can develop optimally so that pupils, and in turn, their schools, perform well. Therefore, it is absolutely necessary that the state provides many incentives for those responsible for education to take appropriate measures in order to improve the quality of education and thereby increase the pupil output. Within this context, institutional factors play a central role, which will be further discussed later in this paper.

In this essay, different aspects are presented and analyzed in order to make suggestions regarding how to improve education and training policy. Basically, the objective is to maximize the student performances, which are evaluated by international tests such as PISA and TIMSS. For this purpose, we use suitable empirical studies. Our analysis focuses on institutional factors such as competition in the school system, school autonomy, responsibility, and an appropriate combination of responsibility and autonomy. First, we review the role of financial resources and teacher quality. In the following discussion, we will derive policy recommendations for education and training policy. Figure 1 gives an overview of the main politico-economic measures for improving education and school policy. 


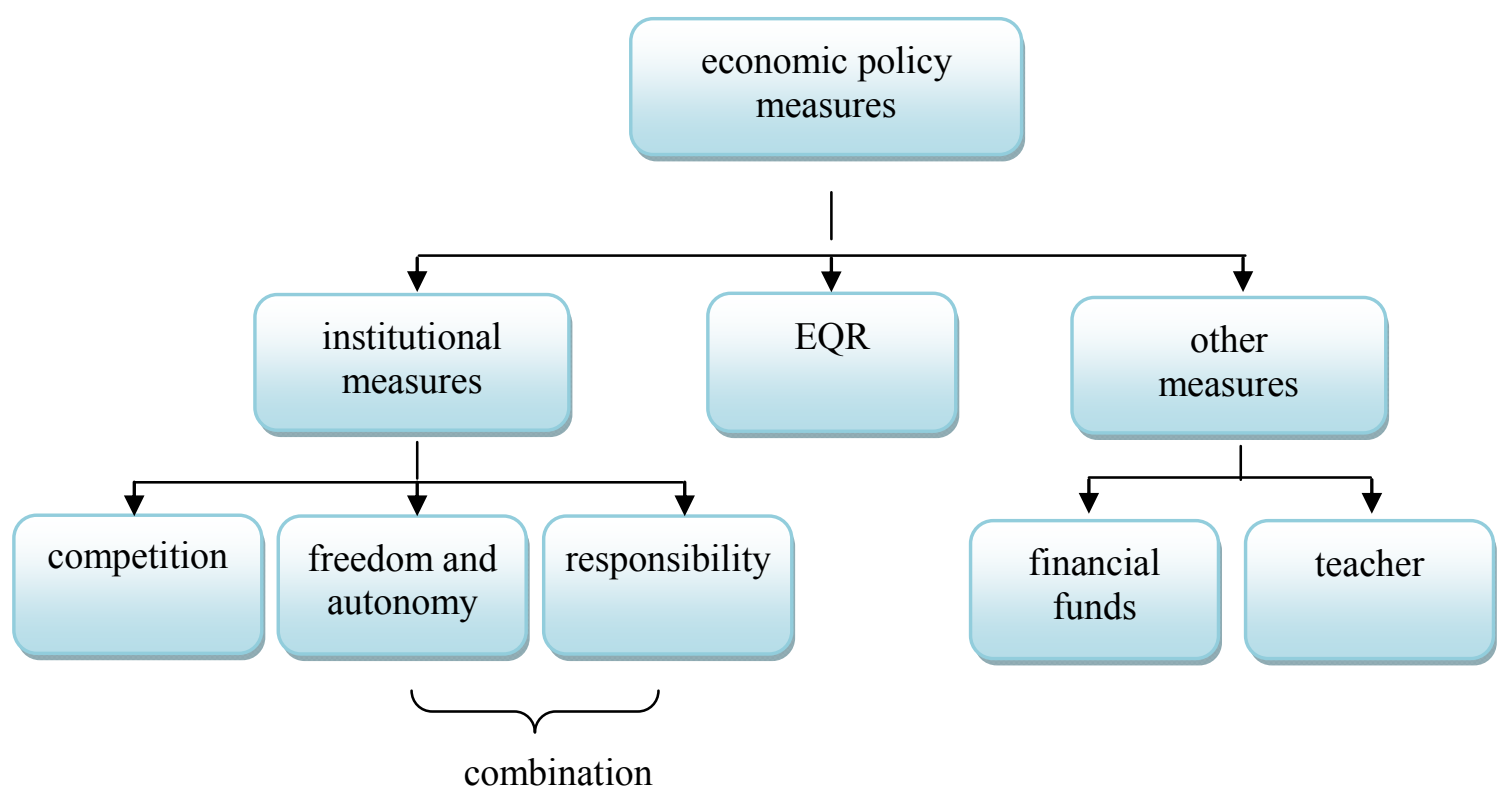

Figure 1. Measures for designing education and school policy

\section{The Role of Financial Resources and Teacher Quality}

Educational policy in the countries we examined focuses mainly on the use of financial resources to reduce class size or to increase the teachers' pay. The question is whether these investments in the quantity of education improve the performance on students and consequently improve the human capital stock of a country or they fizzle and do not support the growth process of the country. The following studies focus on factors, such as class size, as well as on aggregate variables, such as the total spending on education (see Hanushek 2003, pp. 66f.). Several studies show that there is no relationship between the educational expenditure per capita and the educational output.

Hanushek and Wössmann (2010, p 34) illustrate that for the OECD countries except Turkey and Mexico, the average results achieved in mathematics in the PISA study of 2006 have no connection to the educational expenditure up to a maximum of $\$ 20,000$ per student. Further analysis shows that there is only a weak positive correlation between educational spending and educational output. However this correlation disappears completely when the expenditures stay under $\$ 25,000$ per student (see Hanushek \& Wössmann 2010, pp. 34f.). The empirical work of Hanushek (2003), Wössmann (2007a) and Gundlach, Wössmann and Gmelin (2001) have demonstrated similar conclusions: They identified only a weak correlation between educational spending and students' performance.

Politicians usually note that a way to improve the educational performance of pupils is to reduce class size. This policy follows the argument that students would perform better if the teachers were able to give each student more attention. However, this type of education policy costs the public a great deal due to the additional demand for teachers. But what are the returns of such policies in terms of educational performance?

$>$ Wössmann (2005b, p 484) concludes that the reduction in class size is not the driving force for improving students' performance. The analysis of 12 European educational systems could not demonstrate that the reduction in class size has had positive effects on the students' outcomes. Therefore, the author expresses serious doubts about a school policy, which only aims at reducing class sizes.

$>$ In contrast, the studies by Hoxby (2000) and Krueger (1999) show that reducing class size has positive effects on student output. Particularly pupils in lower grade levels learn better in smaller classes.

These empirical findings show that the impact that reducing class size has on students' performance is ambiguous. However, many education experts and politicians have a tendency to overestimate the importance of policies that are focused on reducing class size and not on improving the quality of education.

On the other hand, the quality of the teachers also plays an important role in student performance. Empirical studies show that certain teachers are able to create a higher educational output than other teachers. 
$>$ Rockoff illustrates (2004, pp. 274f.) that there are large differences in the quality of teachers between schools. This study shows specifically that the quality of teachers and their experience are positively correlated with the mathematical and literary results in international comparisons. Students' achievements vary depending on the teacher's work experience. Students taught by a teacher with 10 or more years of experience achieved more points than the students with a less experienced teacher.

$>$ There is no correlation between a teacher's level of education and his or her achievements in class. According to Rivkin, Hanushek and Kain (2005, S. 449), there is no clear proof that a better education in terms of a master's degree improves the teacher's achievements for a good class. Similar results are provided by Rivkin, Hanushek and Kain (2005), Hanushek, Kain, O'Brien and Rivkin (2005), and Kane, Rockoff and Staiger (2006). They also conclude that certain teachers are able to increase the students' achievements significantly, but it is not due their educational levels.

The quality of teachers differs from country to country. The reasons for these differences among countries are complex and cannot be fully explained by empirical analyses. Some of the differences in quality are due to teachers' experiences, but this argument cannot describe all of the variances. There are still other factors that have not yet been implemented in the empirical studies (cf. Hanushek \& Wössmann 2007, pp. 65f.). From a research perspective, it is not entirely clear which characteristics make a teacher a good teacher. The inability to identify specific characteristics of good teachers makes it difficult to anchor a real high quality of teachers at schools nationwide. In this area, further efforts are needed.

\section{Institutional Structures and Incentives in Training and School Systems}

Institutions and education are closely linked to each other. The establishment of a well-functioning training and school system is very difficult without appropriate institutional structures. Incentives play an extremely important role in the education system. Education delegates need to be exposed to high degree incentives to improve student performances. Incentives encourage people to make an effort to improve the quality of education as a whole, particularly the students' output, but only if these incentives are strong enough. Otherwise, education delegates behave opportunistically and maximize their own profit, rather than the benefit to the students.

$>$ The institutions of the educational system are responsible for monitoring the incentives in order to produce high-quality education. Therefore, it is assumed that the institutions supply an important input to develop the quality of education (Wössmann 2007b, p 476).

$>$ The major task of economic policy is to design the institutional framework in a way that can contribute to the improvement of the quality of education and academic institutions. Institutional reforms by governments generally refer to changes in competition between schools, to school autonomy in school-related decisions, and to a system of central examinations.

$>$ The participation of the private sector in education, the decentralization of responsibilities at schools, and the measures to provide transparency are appropriate starting points for improving the quality of education in schools (see Wössmann 2007b, pp. 474f).

Finally, increasing human capital stock as a result of increasing the students' cognitive abilities leads to positive economic developments in the country. This connection has been shown in theoretical and empirical models. This suggests that the institutional frameworks in education play an extremely important role and should be used by the economic policy as an instrument for promoting and stabilizing economic development.

\section{Competition between Schools}

Institutional factors play an important role in the learning process of students. But why should more competition between schools lead to an increase in the quality of education?

\subsection{Promoting Competition among Sponsors}

Economic policy encourages competition between public and private schools by taking part of the private sector in education. This means that schools have a strong incentive to offer high quality learning opportunities to customers - parents and students. Parents want to send their children to "productive" schools, where they learn as much as possible. The increasing incentives on the part of educational authorities lead to a high demand and improve the quality of education. Otherwise, the market mechanisms sort out schools of lower quality due to low demand. The competition disciplines schools to avoid inefficiency and to operate effectively, which will finally increase the quality of education. Therefore, school executives receive enough incentives from the competition 
between public and private schools, so they can optimally use the available resources to maximize the education output of the students and finally win the favor of the parents (see Wössmann 2007b, p 476).

The schools assume that the incentive to "survive" promotes the willingness of school managers to increase the educational student output and also contributes to the development of innovative concepts in the sense of "Schumpeterian pioneer companies". Further incentives are good school curricula, a high level of well-trained teachers as well as suitable materials and equipment in schools (see Hanushek \& Wössmann 2010, p 36). However, it is observed that many countries manage and finance a good portion of their school system at the state level and only a small proportion is organized privately. The consequence is that in such educational and school systems, there is only little competition which antagonizes the incentive to improve the quality and find a disciplined way to manage costs. Furthermore, it is difficult to ensure a high quality education in the public system because there are enormous barriers to overcome if someone wishes to leave a lower-quality school. This makes changing schools very difficult.

\subsection{Results of Empirical Studies}

To examine the effect of competition on the educational performance of students, Wössmann (2007b, p 482) analyzes international student achievement tests, such as TIMSS, TIMSS-Repeat, PISA, and PIRLS. He concludes that pupils in countries with a relatively high proportion of privately owned schools perform better on average on international tests than students in countries where the education system is mainly public.

$>$ For example, students achieve 9-10 points more in mathematics and science in TIMSS when the proportion of enrolled students is $14 \%$ higher in privately-managed schools than in public schools.

$>$ A similar relationship exists when a greater proportion of public capital goes into private schools. Even an increase of $1 \%$ in public spending in the private education sector leads to an improvement of 10 points in mathematic performance.

$>$ The PISA studies also have concluded that the deviation between publicly and privately run schools is 16 to 20 test points in all three subjects. Thus, students perform better in those countries that have a higher number of students registered in privately run schools.

Further studies by Wössmann (2005a, 2006), West and Wössmann (2010), and Wössmann, Luedmann, Schuetz and West (2009) show that the existence of competition between schools improves the students' performance at both public and private schools. The countries that combine relatively high public expenditure with a relatively high proportion of privately owned schools achieve the most PISA points. Furthermore, because the state also supports private schools, poor families have the opportunity to send their children to both public as well as private schools. Thus, the use of public capital augments the leeway in decision-making of poorer families. They are no longer dependent on the unilateral choice of public schools. This fact contributes to greater social justice in the school and training system (see Hanushek \& Wössmann 2010, p 37).

Other studies by Neal (1997, 2002), Hoxby (2003), and Howell et al. (2002) provide empirical evidence regarding the positive correlation of school choice and the achievements of the students. Similar effects of competition on the student output are shown in the work by Bradley/Taylor (2002) and Levacic (2004) in England. Also the studies of Sandström and Bergström (2005) and Björklund, Edin, Fredriksson and Krüger (2004) emphasize the significant positive effect that competition has on the quality of educational choices in Sweden. However, there are some reservations concerning the introduction of competition in the educational system. Critical arguments, as described in the papers by Hoxby (2003), Nechyba (2000), and Burgess, McConnel, Propper and Wilson (2007) emphasize that sorting out disadvantaged students or relying on at-times inconsistent empirical results is not wise.

\section{Impacts of School Autonomy}

Another institutional factor that has a significant impact on the quality of education and students performance is the degree of school autonomy. Within this context, school autonomy refers to the question how schools and teachers can make their own decentralized decisions rather than follow centralized standards. The study by Fox and Wössmann (2007, p 451) considers the international PISA test results and identifies that students performance is better in schools that have a high degree of autonomy. The autonomy in decision-making includes the employment and payment of teachers, the choice of teaching material, and other use of financial resources.

Autonomy in these areas promotes the efficient use of resources and increases the motivation of school executives in those schools. In the end, this autonomy leads to better quality education and consequently higher students' performances. Fuchs and Wössmann show that because of higher autonomy, students were 
significantly able to improve their test scores in all subjects of the PISA study. Hoxby (1999), Behrman and King (2001), Nechyba (2003), and Bishop and Wössmann (2004) outline in their empirical studies that decentralizing school-based decisions improves the effectiveness of schools, leads to higher student performances, and increases the motivation of the educational authorities involved. Furthermore, they emphasize that when teachers are exposed to strong incentives and when they can arrange lessons independently and with appropriate teaching methods, there is a noticeable increase of the student outputs. The design of appropriate incentive systems promote teachers to make decentralized decisions (see Fuchs \& Wössmann (2007, p. 453f.).

For autonomy to succeed, it must be accompanied by responsibility. Without the assumption of responsibility, the educational authorities would have little incentive to use the opportunity of decentralized decision-making to improve the quality of education, leaving room for opportunistic behavior. But how can we monitor the quality of education? External or centralized tests play an important role in monitoring the attained quality of education in schools.

\section{Responsibility and School Performance}

For the decisions that schools and teachers make, the role of responsibility has a significant impact on the output of the students. Without sufficient incentives, teachers tend to rely on teaching techniques which seem to be the most convenient for them. Such opportunistic behavior leads to poor learning outcomes. The problem is that without central examinations, there is a lack of transparency, so that teachers cannot be held responsible for the low quality of their teaching. Only the introduction of central examinations provides a sufficient incentive for teachers and schools to improve their quality of their teaching. Students' performance can then be measured transparently so that the quality of their teaching is easier to verify. In this case, teachers will focus more on improving educational outputs and apply individual teaching methods. Consequently, monitoring the performance through central examinations leads to more transparency regarding the quality of education in schools and makes teachers responsible for what and how they teach. The centralized exams are, therefore, a kind of quality control instrument for those who are responsible for education (see Wössmann 2007b, pp. 487f).

An important characteristic of central exams is that they are created by independent bodies and therefore provide independent and comparable information about the educational quality of schools. Parents can use this information to make better decisions regarding which school they choose to send their children to. Empirical studies confirm the statements above about the positive relationship between the acceptance of responsibility on the quality of education and students' performance on international tests.

$>$ Fuchs and Wössmann (2007) show in their work that students perform significantly better in PISA, TIMSS, and TIMSS-Repeat in those countries, which have an external exit examination system, than in countries without central exams.

$>$ The study by Jürges, Schneider and Büchel (2005, p 1151) examined the effects of central exit examinations on student output in Germany. In Germany, some federal states have centralized examinations and others do not. The statistics clearly show that students in federal states with centralized examinations such as Bavaria and Baden-Württemberg achieve better overall results on standardized tests.

> Similar results are available for Canada. The work of Bishop (1997, p 264) highlighted the central importance of final exams for the student output.

Parents taking responsibility to help their children learn their lessons can have a positive influence on student performance. The last point reflects the responsibility which students and their parents have (see Wössmann 2007b, p 488). Even if teachers show interest in the learning progress of students and monitor it by regular test, the results always can be improved. The empirical studies conclude that the role of responsibility in schools and in the training system plays a central role and needs to be taken into account by the economic policies.

\section{Combination of Centralized Examinations and Autonomy}

The combination of autonomy and centralized examinations is essential for the performance of students as shown above. Therefore, it is interesting to analyze which combination of these institutional factors should be used to optimize the quality of education. The following studies examine this relationship and show that centralized final examinations improve student output the most. In his analysis, Wössmann $(2003,2007 \mathrm{~b})$ considered the results of the TIMSS and TIMSS-Repeat tests in mathematics of about a half-million students in 54 countries. He distinguishes the cases presented below. The autonomy is measured by whether or not the schools are allowed to determine their teachers' salaries.

Student performances are influenced by different combinations of institutional factors like "central exams and autonomy." Figure 2 gives an overview of the possible combinations of institutional factors. 
$>\quad$ The empirical results show that student performance is always the best if schools supply a combination of a high degree of autonomy with a system of central final examinations (Case D). The autonomy of schools to determine teachers' salaries has a positive effect on the test results. In Case $\mathrm{C}$ - central exams, no autonomy - the students also show good results, although little less than in the case of D with school higher autonomy (cf. Wössmann 2007b, p 490). Poorer results surface in Case A - no autonomy, no core exams. Even worse results are recorded in Case $\mathrm{B}$, where there is a good deal of autonomy and no central examinations.

$>\quad$ As long as schools cannot be held responsible for their actions, a high degree of autonomy therefore leads to negative results on the part of students. This is due to the opportunistic behavior of schools executives and teachers (see 490ff Wössmann 2007b).

$>\quad$ In general, the empirical studies identify that students in educational systems with centralized examinations (cases $\mathrm{c}$ and d) achieve better results than in systems without central exams (cases a and b). If the school has a high degree of school autonomy, the students' performance can be further improved (see Wössmann 2003, pp. 53ff.).

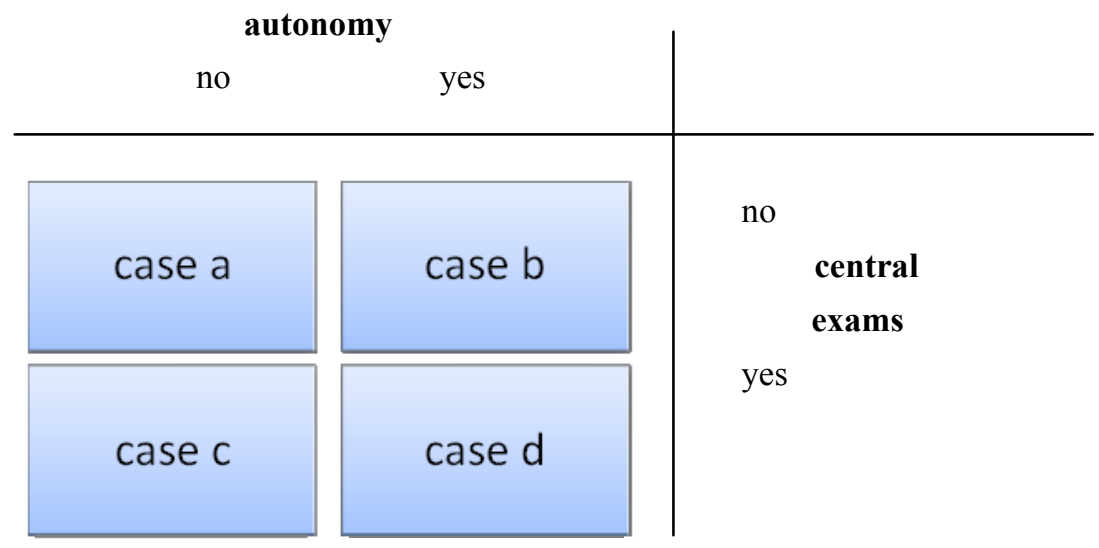

Figure 2. Combination of autonomy and central exams

According to Wössmann, a school's responsibility and autonomy correlate in a complementary relationship. Without the assumption of responsibility, schools behave too opportunistically because their actions are not monitored and therefore they cannot be sanctioned. The educational authorities only have a little incentive to use their autonomy to make efficient decisions. On the other hand, this self-interested behavior causes negative effects on students' performance. Only by introducing central examinations can the decision-makers can be held accountable for their school's results and the opportunistic behavior will be corrected in a manner so that the negative effects of autonomy mentioned above convert into positive effects. In this case, schools have sufficient incentives to use their autonomy for those measures which improve students' performance significantly. Similar effects of autonomy are not only identified in TIMSS and TIMSS-Repeat but also in the PISA studies.

In summary, we can conclude that school autonomy only leads to better educational results if there are sufficient incentives on the part of schools to improve the student performance. A system of central exams, therefore, provides sufficient transparency. It is a prerequisite for an efficient incentive system. The central exams can be understood as the "currency" of schools and the educational system. As a measure of performance and evaluation of schools, the central exams reduce transaction costs, which are caused by asymmetric information between principals and agents. Finally, we can conclude that school autonomy improves the efficiency of the educational and training system. This has the consequence that the human capital improves in the form of increasing cognitive skills and thereby promotes the economic growth of countries in an impressive way.

\section{Discussion and Conclusion}

Using financial resources to reduce class size or to improve the quality of teachers does not necessarily lead to higher performance by students. In this regard, the empirical papers by Wössmann (2005), Hoxby (2000), and Krueger (1999) demonstrate that there is hardly any clear correlation. However, many governments follow this policy and therefore extend their politico-economic efforts in this way. The papers of Hanushek and Wössmann (2010), Hanushek (2003), and Wössmann (2007a) verify in international tests such as PISA and TIMSS that 
there is no correlation between higher per capita spending on education and increasing pupil performances; therefore, there is no positive effect from a macroeconomic viewpoint.

The issues is not any clearer when it comes to the quality of the teachers. On the one hand, the quality of the teachers plays an important role in the learning process of students. For example, the fact that the experience of teachers is important for the pupil performance is shown by the paper by Rockoff (2004). On the other hand, the empirical studies are not able to build up an accurate profile of teachers and recommend specific measures for improving the quality of teachers. Therefore, it is indispensable to search further starting points for the economic policy in order to make the educational and school system more effective and efficient.

Within this context, institutional structures and incentives play a key role in the success of students. Empirical studies demonstrate that institutional factors play an important role in a country's school and educational system. Investigations focused mainly on the role of competition, the importance of school autonomy, the assumption of responsibility for student performances, and an appropriate combination of responsibility and autonomy. International PISA test analyses show that about a quarter of the present total deviations are due to different institutional arrangements in the respective countries. Thus, institutional factors do indeed effect the quality of the education and training system.

Studies of the first institutional factor "competition" by Wössmann (2005a, 2006, 2007), West and Wössmann (2010), and Wössman, Luedmann, Schuetz and West (2009) provide empirical evidence that private competition significantly improves the educational services offered both in public and in private schools. Hence, pupils in countries with a relatively high proportion of privately owned schools perform better on international tests than students in countries where the educational system is mainly public.

Competition for state resources between public and private schools encourage additional incentives which lead to more competition in education and a more efficient use of resources. Schools that do not achieve adequate results are sorted out from the competition. Therefore, the educational authorities need to ensure innovative educational concepts, efficient management of resources, and qualitatively well-trained teachers to improve the educational level of pupils and to assure the existence of the school in the future.

"Autonomy," the second institutional factor, describes the ability of schools to make their own decisions, such as regarding the use of financial resources, hiring of teachers, and the choice of teaching materials. All of these factors have a strong influence on students' performance. The empirical studies by Fuchs and Wössmann (2007), Nechyba (2003), and Behmann and King (2001) conclude that a high degree of autonomy leads to higher efficiency of financial resources. Schools and teachers have the ability to respond to students individually with appropriate teaching methods. Because teachers know the students best, this decentralization of decisions is more reasonable than blanket rules by a central authority.

"Responsibility," the third institutional factor, means that teachers are responsible for the learning outcomes of their students. The establishment of an appropriate incentive system combined with autonomy helps to increase the students' output, which is confirmed by empirical results in international tests. Thus, at those schools where a high degree of autonomy exists and teachers experience sufficient incentives to increase the quality of education in their classes, the pupils score better in PISA in all subjects. Therefore, responsibility on the part of schools and teachers plays a fundamental in the quality of the teaching at a given school. But how can we verify teaching or the quality of education at all?

Educational authorities are under examination because pupil performance is transparently tested by central final examinations, whereby schools and teachers need to be measured with each other in the results of the examinations. Empirical studies by Fox and Wössmann (2007), Jürges, Schneider and Büchel (2005), and Bishop (1995) show that students perform significantly better in TIMSS, TIMSS-Repeat, and PISA in countries where a system of central examinations exists. This result can also be observed in Germany. In federal states with a centralized examination system, students achieve perform much better than in federal states without a centralized examination system.

The importance of the institutional factors autonomy and responsibility has been explained in detail. This raises the question regarding what proportion or combination of autonomy and responsibility should be used. This represents the fourth institutional factor. The analyses by Wössmann $(2005,2007)$ and Fox and Wössmann (2007) confirm that a high degree of school autonomy hand-in-hand with a system of central examinations show the best student outcomes. Schools can only be disciplined by central examinations, so that they can use their autonomy in a profitable way to increase the quality of education. If there are no central examinations, education managers behave opportunistically and try to maximize their own benefit instead the performance of their students. In this case, a high degree of autonomy can even decrease students' performance. 
The positive relationship between school autonomy and central exams on students' performances can be demonstrated empirically. Countries with these institutional characteristics register the best performances in international tests such TIMSS, TIMSS-Repeat, and PISA. Therefore, responsibility and autonomy are complementary to each other. The question of the proper mix of these two characteristics is important for the school and educational system. In summary, it can be stated that the institutional factors - more competition in the school system, more school autonomy, more responsibility, and a suitable combination of responsibility and autonomy - are keys to student performances on international tests. By arranging this institutional framework in a proper ratio, a country can improve the quality of education significantly, as shown by empirical studies.

The quality of the school and educational system is much more important than the quantity. After all, this quality is decisive for the human capital of a whole country, which, in turn, is responsible for the economic growth of an economy. Therefore, appropriate politico-economic measures need to be taken to create this institutional framework. Thus, it is the task of economic policy to develop a country's institutional framework so that the quality of the education and training and therefore the human capital can be improved. The research results of international empirical studies discussed in this paper provide a range of approaches and proposals that governments could use as a guide or as a "cornerstone" for the design of their school and educational systems.

\section{References}

Behrman, J. R., \& King, E. M. (2001). Household Schooling Behaviors and Decentralization. Economics of Education Review, 20, 321-341.

Bishop, J. H., \& Wössmann, L. (2004). Institutional Effects in a Simple Model of Educational Production. Education Economics, 12, 17-38.

Bishop, J. H. (1997). The Effect of National Standards and Curriculum-Based Examinations on Achievement. American Economic Review, 87(2), 260-264.

Björklund, A., Edin, P., Fredriksson, P., \& Krueger, A. (2004). Education, Equality and Efficiency: An Analysis of Swedish School Reforms during the 1990s, Uppsala, Institute for Labour Market Policy Evaluation.

Bradley, S., \& Taylor, J. (2002). The Effect of the Quasi-Market on the Efficiency-Equity Trade-off in the Secondary School Sector. Bulletin of Economic Research, 54, 295-314. http://dx.doi.org/10.1111/1467-8586.00154

Burgess, S., McConnell, B., Propper, C., \& Wilson, D. (2007). The Impact of School Choice on Sorting by Ability and Socio-Economic Factors in English Secondary Education, In Wössmann L., Peterson, P.E. (Eds.), Schools and the Equal Opportunity Problem, Cambridge, MA, MIT Press, 273-291.

Fuchs, T., \& Wössmann, L. (2007). What Accounts for International Differences in Student Performance? A Re-Examination using PISA Data. Empirical Economics, 32, 433-464. http://dx.doi.org/10.1007/s00181-006-0087-0

Gundlach, E., Wössmann, L., \& Gmelin J. (2001). The Decline of Schooling Productivity in OECD countries. Economic Journal, 111(471), C135-C147. http://dx.doi.org/10.1111/1468-0297.00624

Hanushek, E. A., \& Wössmann, L. (2007). The Role of School Improvement in Economic Development, CESifo Working Paper Series 1911, CESifo Group Munich. Retrieved from http://ssrn.com/abstract=963972

Hanushek, E. A., \& Wössmann, L. (2010). How much do Educational Outcomes Matter in OECD Countries? CESifo Working Paper Series 3238, CESifo Group Munich. http://dx.doi.org/10.1111/j.1468-0327.2011.00265.x

Hanushek, E. A. (2003). The Failure of Input-Based Schooling Policies. Economic Journal, 113(485), 64-98. http://dx.doi.org/10.1111/1468-0297.00099

Hanushek, E. A., Kain J. F., O' Brien, D. M., \& Rivkin S. G. (2005). The Market for Teacher Quality, Working Paper No. 11154, National Bureau of Economic Research. Retrieved from http://ssrn.com/abstract=669453

Howell, W. G., Wolf, P. J., Campbell, D. E., \& Peterson, P. E. (2002). School Vouchers and Academic Performance: Results from Three Randomized Rield Trials. Journal of Policy Analysis and Management, 21. http://dx.doi.org/191-217. 10.1002/pam.10023

Hoxby, C. M. (1999). The Productivity of Schools and Other Local Public Goods Producers. Journal of Public Economics, 74, 1-30.

Hoxby, C. M. (2000). The Effects of Class Size on Student Achievement: New Evidence from Population Variation. Quarterly Journal of Economics, 115(4), 1239-1285. http://dx.doi.org/10.2139/ssrn.144929 
Hoxby, C. M. (2003). School Choice and School Competition: Evidence from the United States. Swedish Economic Policy Review, 10, 9-65.

Jürges, H., Schneider, K., \& Büchel, F. (2005). The Effect of Central Exit Examinations on Student Achievement: Quasi-Experimental Evidence from TIMSS Germany. Journal of the European Economic Association, 3, 1134-1155.

Kane, T. J., Rockoff, J. E., \& Staiger, D. O. (2006). What Does Certification Tell Us About Teacher Effectiveness? Evidence from New York City, Working Paper No. 12155, National Bureau of Economic Research. http://dx.doi.org/10.1016/j.econedurev.2007.05.005

Kant, I. (2000). Beantwortung der Frage: Was ist Aufklärung. In Weischedel, W. (Hrsg.), Schriften zur Anthropologie, Geschichtsphilosophie, Politik und Pädagogik, Bd. 1. Frankfurt a. M., 53-61.

Krueger, A. B. (1999). Experimental Estimates of Education Production Functions. Quarterly Journal of Economics, 114(2), 497-532. http://dx.doi.org/10.1162/003355399556052

Levacic, R. (2004). Competition and the Performance of English Secondary Schools: Further Evidence. Education Economics, 12, 177-193.

Neal, D. A. (1997). The Effects of Catholic Secondary Schooling on Secondary Achievement. Journal of Labor Economics, 15, 98-123.

Neal, D. A. (2002). How Vouchers could change the Market for Education. Journal of Economic Perspectives, 26, 25-44. http://dx.doi.org/10.1257/089533002320950966

Nechyba, T. J. (2000). Mobility, Targeting, and Private-School Vouchers. American Economic Review, 90, 130-146.

Nechyba, T. J. (2003). Centralization, Fiscal Federalism, and Private School Attendance. International Economic Review. http://dx.doi.org/44, 179-204.10.1111/1468-2354.t01-1-00066

Rivkin, S. G., Hanushek, E. A., \& Kain, J. F. (2005). Teachers, Schools, and Academic Achievement. Econometrica, 73(2), 417-458.

Rockoff, J. E. (2004). The impact of individual teachers on student achievement: Evidence from panel data. American Economic Review, 94, 247-252. http://dx.doi.org/10.1257/0002828041302244

Sandström, F. M., \& Bergström, F. (2005). School Vouchers in Practice: Competition will not hurt you, Journal of Public Economics, 89, 351-380.

West, M. R., \& Wössmann, L. (2010). Every Catholic Child in a Catholic school: Historical Resistance to State Schooling, Contemporary Private Competition and Student Achievement across Countries. Economic Journal, 120(546), F229-F255.

West, M. R., \& Wössmann, L. (2010). School Choice International: Higher Private School Share Boosts Test Scores. Education Next, 9(1), 54-61.

Wössmann, L. (2003). Central Exams as the "Currency" of School Systems: International Evidence on the Complementarity of School Autonomy and Central Exams. DICE Report - Journal for Institutional Comparisons, 1, 46-56.

Wössmann, L. (2005a). Public-Private Partnerships in Schooling: Cross-Country Evidence on their Effectiveness in Providing Cognitive Skills, Program on Education Policy and Governance. Research Paper PEPG 05-09, Cambridge, MA, Harvard University.

Wössmann, L. (2005b). The Effect Heterogeneity of Central Exams: Evidence from TIMSS, TIMSS-Repeat and PISA, Education Economics, 13, 143-169. Retrieved from http://ssrn.com/abstract=625962

Wössmann, L. (2006). Public-Private Partnerships and Schooling Outcomes across Countries, CESifo Working Paper Series 1662, CESifo Group Munich. Retrieved from http://ssrn.com/abstract=889519

Wössmann, L. (2007a), International Evidence on Expenditure and Class Size: A Review. Brookings Papers on Education Policy 2006/2007, 245-272.

Wössmann, L. (2007b). International Evidence on School Competition, Autonomy and Accountability: A Review. Peabody Journal of Education, 82, 2-3, 473-497. http://dx.doi.org/10.1787/246402531617

Wössmann, L., Luedemann, E., Schuetz, G., \& West, M. R. (2009). School Accountability, Autonomy, and Choice around the World. Cheltenham, UK: Edward Elgar. http://dx.doi.org/10.1007/s00712-010-0111-x 